\title{
Association of genetic variants with prostate cancer in Africa: a concise review
}

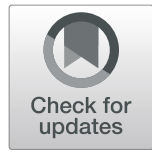

\author{
Emmanuel Acheampong ${ }^{1,2^{*}}$ (D), Evans Asamoah Adu', Christian Obirikorang ${ }^{1}$, George Amoah ${ }^{3}$, \\ Osei Owusu Afriyie ${ }^{4,5}$, Joseph Yorke ${ }^{6}$, Enoch Odame Anto ${ }^{2,7}$, Michael Adu Gyamfi ${ }^{7}$, \\ Emmanuella Nsenbah Acheampong ${ }^{1}$, Christian Kofi Gyasi-Sarpong ${ }^{3}$ and Francis Agyemang Yeboah ${ }^{1}$
}

\begin{abstract}
Background: Prostate cancer (PCa) has one of the highest heritability of all major cancers, where the genetic contribution has been documented, and knowledge about the molecular genetics of the disease is increasing. However, the extent and aspects to which genetic variants explain PCa heritability in Africa are limited.

Main body: In this review, we summarize studies that highlight how identified genetic variants explain differences in PCa incidence and presentation across ethnic groups. We also present the knowledge gaps in PCa genetics in Africa and why Africa represents an untapped potential ground for genetic studies on PCa. A significant number of genome-wide association studies, linkage, and fine-mapping analyses have been conducted globally, and that explains 30-33\% of PCa heritability. The African ancestry has a significant mention in PCa incidence and presentation. To date, the candidate gene approach has replicated 23 polymorphisms including dinucleotide and trinucleotide repeats in 16 genes. CYP17-rs743572, CYP3A4-rs2740574, CYP3A5-rs776746, CYP3A43-rs501275, and haplotype blocks, containing these variants, are significantly associated with PCa among some population groups but not others. With the few existing studies, the extent of genetic diversity in Africa suggests that genetic associations of PCa to African ancestry go beyond nucleotide sequence polymorphisms, to a level of environmental adaptation, which may interpret genetic risk profiles. Also, the shreds of evidence suggest that evolutionary history contributes to the high rates of PCa relative to African ancestry, and genetic associations do not always replicate across populations.
\end{abstract}

Conclusion: The genetic architecture of PCa in Africa provides important contributions to the global understanding of PCa specifically the African-ancestry hypothesis. There is a need for more prostate cancer consortiums to justify the heritable certainties of PCa among Africans, and emphasis should be placed on the genetic epidemiological model of PCa in Africa.

Keywords: Genetic variants, Risk alleles, Prostate cancer

\footnotetext{
* Correspondence: emmanuelachea1990@yahoo.com

'Department of Molecular Medicine, College of Health Sciences, School of Medical Science, Kwame Nkrumah University of Science and Technology (KNUST), Kumasi, Ghana

${ }^{2}$ School of Medical and Health Science, Edith Cowan University, Joondalup, Australia

Full list of author information is available at the end of the article
}

\section{Springer Open}

(c) The Author(s). 2021 Open Access This article is licensed under a Creative Commons Attribution 4.0 International License, which permits use, sharing, adaptation, distribution and reproduction in any medium or format, as long as you give appropriate credit to the original author(s) and the source, provide a link to the Creative Commons licence, and indicate if changes were made. The images or other third party material in this article are included in the article's Creative Commons licence, unless indicated otherwise in a credit line to the material. If material is not included in the article's Creative Commons licence and your intended use is not permitted by statutory regulation or exceeds the permitted use, you will need to obtain permission directly from the copyright holder. To view a copy of this licence, visit http://creativecommons.org/licenses/by/4.0/. 


\section{Background}

Prostate cancer $(\mathrm{PCa})$ is the fifth leading cause of death from cancer in men, with an estimated 307,000 deaths representing $6.6 \%$ of total male cancer mortality [1]. Among men of African descent, $\mathrm{PCa}$ is the leading cancer in terms of incidence and mortality with approximately 22.0 per 100,000 population of men affected [2]. There is a consensus that $56 \%$ of new cases of cancers are reported in Africa and other low-middle-income countries which are projected to reach about $70 \%$ by 2030 [3-5]. Regional reports indicate that the ageadjusted incidence per 100,000 population ranges from 10.6 in Northern Africa to $61.7 \%$ in Southern Africa [6]. In sub-Saharan Africa (SSA) alone, disability-adjusted life years (DALYs) and mortality from prostate cancer increased from 100,200 to 219,700 and 5600 to 12,300 , respectively over a decade (1990-2010) [7, 8]. Until recently, major unexplained differences exist in $\mathrm{PCa}$ incidence and mortality between countries in Africa, subjected to socioeconomic factors and genetics. For example, the age-standardized PCa incidence rate per 100 , 000 is 37.1 in Uganda [9], 30.5 in Benin [10], 30.26 in Eritrea [11], 24.5 in Mozambique [12], 20.4 in Northern Uganda [13], 16.5 in Mauritius [14], and 4.3 in Eastern Morocco [15]. Aside from these African continentspecific differences, there are also significant geographical differences largely due to the underlying biology of prostate carcinogenesis, the variation in access to screening and treatment, and exposure to risk factors of $\mathrm{PCa}$ [6]. However, the proportion of racial, ethnic, or geographical differences in $\mathrm{PCa}$ incidence that can be explained by these factors is relative and poorly understood.

PCa has one of the highest heritability of all major cancers [16-19], where the genetic contribution to PCa risk has been documented and knowledge about the molecular genetics of the disease is increasing and evolving. For instance, family based linkage studies have identified both common and ethnic-specific loci that partly explain the diversity in PCa incidence. Linkage signals including 12q24, 1q24-25, and 8q24 are common to both European and non-European descendants and have been widely replicated in candidate gene studies across diverse ethnic groups [20]. Also, as of 2014, genome-wide association studies (GWAS) have identified 76 susceptibility loci associated with PCa risk, and approximately $30 \%$ of the familial risk is due to such variants [21]. This typifies that understanding the genetic risks of $\mathrm{PCa}$ is essential to personalized medicine and a bridge in understanding differences in incidence and mortality outcomes.

In this study, we review topics covered on the genetics of PCa in Africa from January 1990 to September 2020 with detailed sections on (1) inheritance and Africanassociated risk, (2) GWAS, and (3) candidate gene studies in PCa. The review also highlighted the gaps in knowledge and prospects in the field to translate the clinical utility of these genetic variants, hitherto undecided. Our literature search included Google Scholar, PubMed, Web of Science, and Scopus. Medical Subject Heading (MeSH) Terms of PCa (Prostatic Neoplasms) were tagged to all countries in Africa across the online databases.

\section{Inheritance and African-associated PCa risk}

In 2015, a study among first-degree relatives in Senegal revealed that being black and having a first-degree relative with PCa does not appear to increase the risk of $\mathrm{PCa}$ [22]. While this finding remains to be confirmed or refuted among other African populations, several studies [23-26] among men with African heritage have reported a strong familial aggregation of PCa. Unfortunately, comprehensive meta-analyses conducted thus far, which provide evidence of familial aggregation of $\mathrm{PCa}$, did not include any study from Africa. Thus, there are unclear answers to what aspects of genetic risk contribute to $\mathrm{PCa}$ incidence in Africa. Accordingly, familial studies are needed to evaluate the true estimate of $\mathrm{PCa}$ heritability in Africa.

Petersen et al. [27] reported a stronger link between KhoeSan ancestry (in South Africa) and high-risk of $\mathrm{PCa}$, which can explain a 2-fold increase in PCa presentation in Black South Africans compared with African Americans (AA). Typical of this finding, the genetic contribution to the burden of $\mathrm{PCa}$ among $\mathrm{AA}$ has been traced to West/West-Central Africa that shares about $82 \%$ of their ancestral genes [27, 28]. To hold this fact, it means that modern men of African ancestry are not unlikely to have undergone selective pressure and possess $\mathrm{PCa}$ risk signatures in their genome with possible familial aggregation. Accordingly, these signatures may be conserved in men of African ancestry including the AA, which may clarify the unexplained $57 \%$ PCa heritability among such populations [19]. Comprehensive studies on familial aggregation of $\mathrm{PCa}$ among Africans, especially men from West/Western-central Africa, are needed to understand population risk and extract evidence for personalized preventive strategies.

\section{Risk alleles at $8 \mathrm{q} 24$ region in the African population}

Various models have been employed to uncover the landscape of genetic variations associated with $\mathrm{PCa}$. In Africa, the GWAS and candidate gene association approach are the most used models. Genetic variants of moderate-to-low-risk rather than rare variants with high penetrance have been widely investigated across Africa, especially the African MadCap Network. The first study that tested the transferability of European and AA common shared variants [20] in the West-African population 
(Nigeria and Cameroon) observed that SNPs rs6983561, rs7008482, and rs16901979 were significantly associated with PCa risk [29]. At the same time, they reported that SNPs rs6983267, rs7008482, and rs7000448 which have low penetrance $(2-4 \%)$ in the European population were prevalent in more than $84 \%$ of the West African population. Similarly, a prior study by Haiman et al. [30] reported that the risk allele at the strongest SNP-rs16901979 associated with $\mathrm{PCa}$ revealed higher penetrance in West Africans (54\%) than European Americans (3\%).

Han et al. [31] conducted a fine mapping of the $8 \mathrm{q} 24$ PCa-risk region $(127.8-128.8 \mathrm{Mb})$ to search for novel associations with common and rare variations among men of African Ancestry. Three ancestry-specific signals (rs72725879, rs114798100, and rs111906932), one of which is novel (rs111906932) located within or near some PCa-associated long noncoding RNAs (lncRNAs), including PRNCR1, PCAT1, and PCAT2, were identified. These associations were replicated in Ghanaian and Ugandan men [31]. Also, a comprehensive resequencing analysis of $250 \mathrm{~kb}$ region of $8 \mathrm{q} 24.21$ in Ghanaian men replicated similar findings [32]. Similarly, 8q24 risk region marked by ancestry-specific risk variant rs72725854, near lncRNAs of PCAT1, accounted for $12 \%$ of PCa risk in the Ugandan population [33]. Moreover, regions marked by rs7008482 and rs6983267 were replicated in the Black South African mixed population [34]. The report of Chung et al. [32] indicated that all 8 PCa-associated loci and rs13252298 in 8q24 are monomorphic in the Ghanaian population. This represents that both ancestryspecific rare and common variants, as well as commonly shared variants, are present in the African population. For all the studies, West African men have a much higher prevalence of 8q24-risk alleles than other populations of European and Asian ancestry which may explain the African-ancestry risk burden of $\mathrm{PCa}$ among AA population.

The overall findings suggest that rarer genetic variation in the $8 \mathrm{q} 24$ region may contribute, in part, to the greater risk of $\mathrm{PCa}$ among the African population. Ahmadiyeh et al. [35] demonstrated that several independent polymorphic variants on chromosome 8q24 may produce a conventional biological mechanism that promotes the disease or regulation of nearby genes (cisregulation) or genes on other chromosomes (trans-regulation). Pomerantz et al. [36] also indicated that the $8 \mathrm{q} 24$ locus harbors previously unannotated microRNAs (miRNAs) which are involved in cis-regulation of distal genes and affecting RNA expression.

The significance of 8q24-risk alleles has been demonstrated in a recent study among the Ugandan population [33]. Polygenic risk score including 8q24-risk alleles has 2-times predictive ability than score constructed without 8q24-risk alleles [33], suggesting that variation in this region may prove vital for risk classification among the African population. Common variants including rs7008482, rs72725879, and rs114798100 were transferable in more than one population group in Africa (Table 1). However, rs6983561 and rs16901979 were replicated in some population group in Africa but not others (Table 1), although there were relatively high allele frequencies in such populations. This finding also suggest that population structure and context-specific factors influence the definition of risk alleles for a population group.

Other risk variants from genome-wide association studies In GWAS [37, 38], 30 variants were identified to be associated with PCa in a prostate cancer study in a Ghanaian population. However, the most promising association was the 10p14 locus marked by introns of noncoding RNAs (rs7918885; 358kb 5' of GATA3, RP11-543F8), which depicts evidence of transferability in the AA population. Subgroup analysis revealed variants at 5q31 (lead SNP PCDHA1-rs34575154), 22q13.31 (CELSR1-rs6008813), 7q31.31 (rs12537079; 61kb 5' of AC003084.2; $119 \mathrm{~kb} 5^{\prime}$ of NAA38), and 2q14.2 (rs12477565; AC012363.13; 22kb 5' of INHBB), associated with GS $\geq 7$ cancers. SNPs at Xq28 (rs985081; 22kb 3' of IDS) and 6q21 (rs2185710; 84kb 3' of U6) were associated with low GS $<7$ cancers.

In a genome-wide association meta-analysis among men of African ancestry, 13q34 candidate signals located $5^{\prime}$ of the gene IRS2 and $3^{\prime}$ of a long noncoding RNA (rs75823044) and 22q12.1 candidate functional allele in the CHEK2 gene were novel signals found only in men of African ancestry [39]. Additionally, according to Fernandez et al. [34], rs10993994 (10q11) showed evidence of transferability in South-African mixed ancestry men. A study by Petersen et al. [27] among the South African Black population identified loci at 2p11.2, 3p14, 8q23, and 22q13.2 associated with the aggressive presentation of PCa. In a further comparative analysis using Fisher's exact significance test with Bonferroni correction, 22q13.2 and 2p11.2 were associated with Gleason score (GS) $>8$. Also, $2 \mathrm{p} 11.2$ was associated with PSA $\geq 20 \mathrm{ng} /$ $\mathrm{ml}$, whereas $8 \mathrm{q} 23$ and $3 \mathrm{p} 14$ were found to be associated with PSA-High-risk prostate cancer. Haplotype and single-marker association analysis identified rs10103786 and rs4504665 within 8q23 that remained significant after correcting for multiple testing [27]. The loci enriched with GS $\geq 8$ and PSA $\geq 20 \mathrm{ng} / \mathrm{ml}, 22 \mathrm{q} 13.2$ and 2 p11.2, have shown evidence of transferability among different population groups [40-43]. The pattern of $\mathrm{PCa}$ risk allele identification from GWAS is typical of a recent report by the MadCap Network that there are significant individual and population-level differences in PCa risk within the Africa population [44]. Among men 
Table 1 Common and rare variants associated with PCa among African population (January 1990-September 2020)

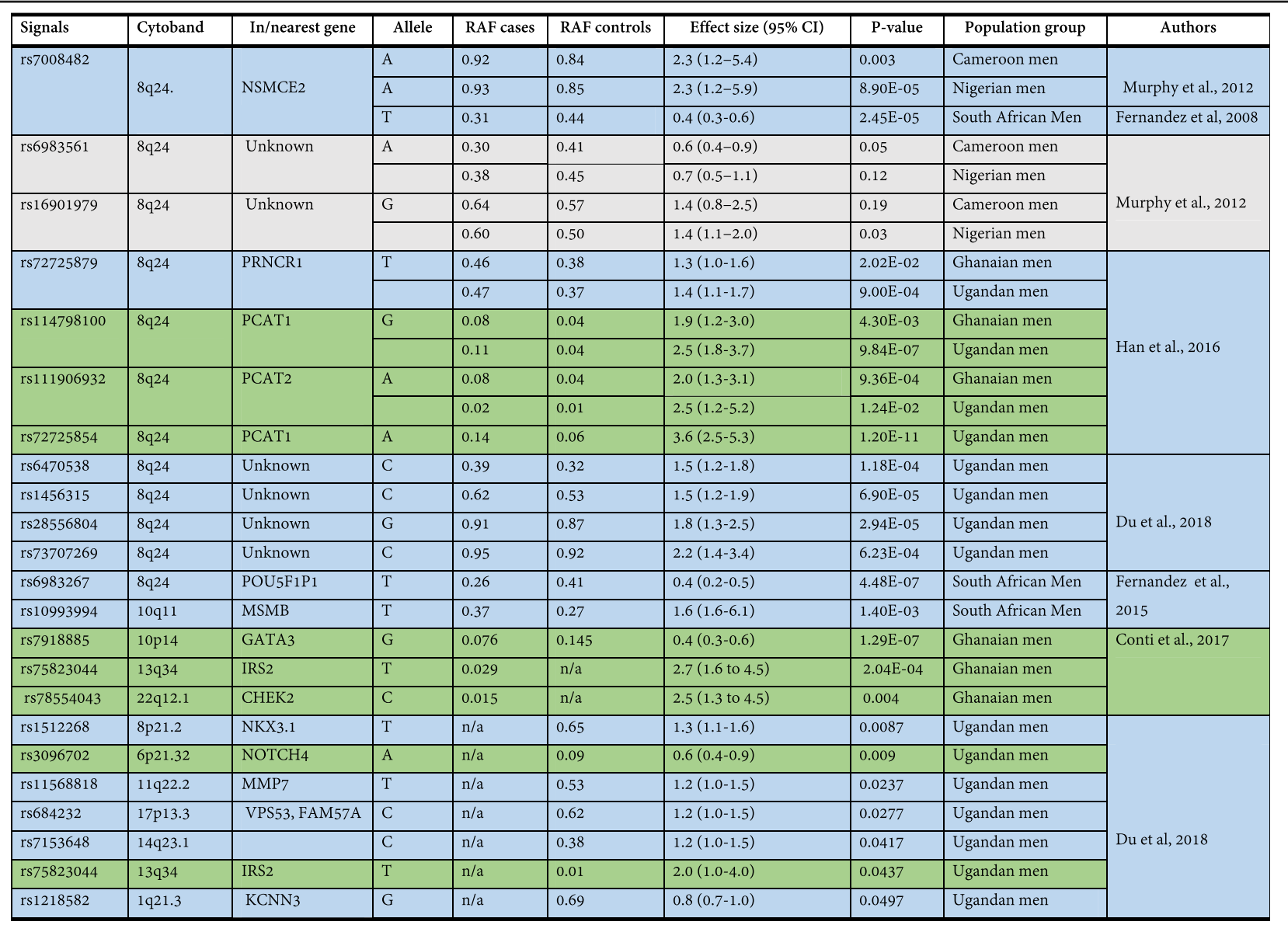

Color representation: green label, ancestry specific signals; blue, commonly shared variance; ash, variants are transferable in some population group but not others

of African ancestry, Haiman et al. [45] identified novel risk variants on 17q21 (rs7210100; odds ratio per allele= $\left.1.51 ; p=3.4 \times 10^{-13}\right)$, which has approximately $5 \%$ penetrance among AA compared with $1 \%$ in the white race. These findings emphasized the significance of GWAS for discovering significant $\mathrm{PCa}$ rare variants associated with the African race [45].

\section{Candidate gene studies}

From January 1990 to September 2020, only 23 polymorphisms, including dinucleotide and trinucleotide repeats, in 16 genes, have been investigated in association with PCa in Africa. The cytochrome variants involved in androgen and estrogen metabolism [46-52] and variants involved in cell proliferation and inflammation $(C O X-2$ and GSTS genes) [53-56] have been investigated in multiple studies. CYP17-rs743572, CYP3A4-rs2740574, CYP3A5-rs776746, CYP3A43-rs501275, and haplotype blocks containing these variants were significantly associated with $\mathrm{PCa}$ among Tunisians and the South African population [46, 47, 49]. However, the association of
CYP3A4-rs2740574 and CYP3A5-rs776746 with PCa was not replicated among Senegalese men [49]. COX-2 polymorphisms (rs3918304 and rs20415) [53] and rs2745557 [54] were transferable to South African and Egyptian populations, respectively. Whereas polymorphisms in GSTM1 but not GSTT1 were associated with PCa in the Tunisian population [55], the association was reciprocated in the Algerian population [56]. Other markers involved in nucleotide excision repair (XPC gene) [57], regulation of cell-cycle progression (ELAC2 gene) [58], and regulation of androgen receptor (HSP7O and AR genes) [59, 60], and COMT [52], studied in single studies, were found to be significantly associated with $\mathrm{PCa}$ risk and severity.

\section{Genetic epidemiological layout of PCa in Africa}

Taking together the shreds of evidence from GWAS and candidate gene association studies, the genetic epidemiological layout of $\mathrm{PCa}$ among the African population is shown in Fig. 1. It appears that the genetic risk of PCa is more complex and results from polygenic inheritance. 


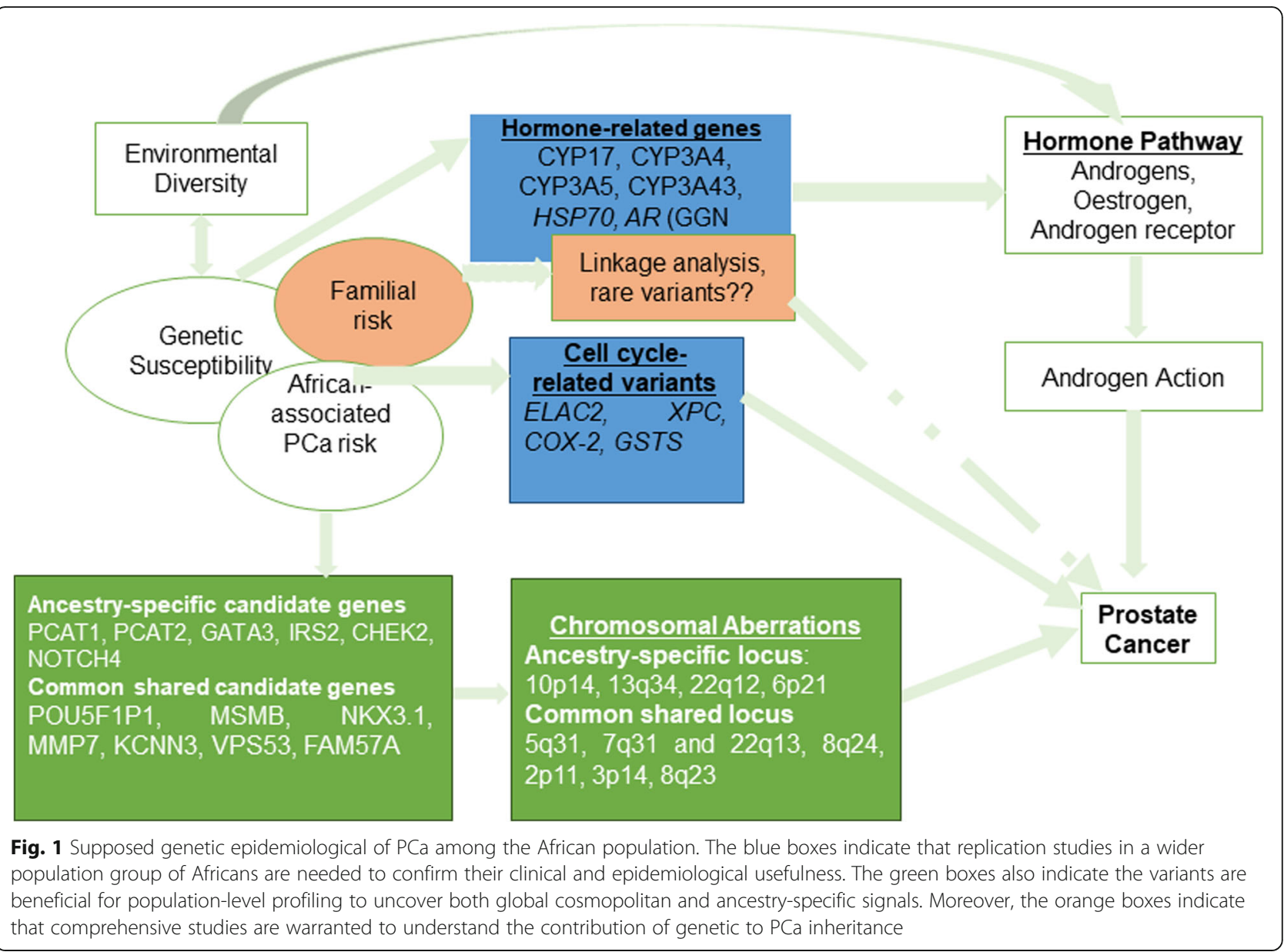

The focus of research, thus far, has been on Africanancestry risk rather than familial aggregation to identify rare variants with larger effect sizes. The $8 \mathrm{q} 24$ locus has the highest number of independently associated common and ancestry-specific variants, which might be clinically relevant. Du et al. [41] have demonstrated that chromatin conformation of 8q24 SNPs exerts long-range tissue-specific control on $M Y C$ expression which gives potential insight into the pathogenesis of prostate cancer. Du et al. [33] further attempted to use risk variants at $8 \mathrm{q} 24$ for risk profiling and exhibited that variation in this region may prove vital for risk classification among the African population. It thus, highlights that population genetic risk score distribution at this region could potentially differentiate $\mathrm{PCa}$ risks for men more accurately according to their risk score percentile. For example, Ugandan men within the $90-99 \%$ of genetic risk scores constructed with 8q24-risk alleles were 4 times more at risk of PCa.

Additionally, other chromosomal aberrations at 2p11, 3p14, 8q23, 13q34, 5q31, 7q31, and 22q13 are associated with the aggressive presentation of PCa among the West African population. Evidence from genetic association studies also affirms the genetic contribution to $\mathrm{PCa}$ among Africans. Generally, variations in androgen and estrogen metabolism genes, cell proliferation genes, and genes involved in inflammation have a high effect on PCa susceptibility (Table 2). The extent of genetic diversity in Africa and the association pattern to PCa suggest that genetic and environmental exposure concurrently interpret genetic risk profiles. Unfortunately, there is limited data in Africa to support any hypothesis in this regard. The heterogeneity in risk allele frequencies, nonreplication of risk variant, represents that diverse populations with African ancestry might share some common prostate cancer susceptibility alleles that may be different from the non-African populations.

\section{Knowledge gaps, prospects, and clinical implications}

The focus of research on the genetics of PCa in Africa has been the African-ancestry risk hypothesis. Therefore, available data $[37,38]$ provides evidence of the high-risk profile of AA from African-ancestry with unresolved issues of being black and having a first-degree relative with PCa not associated with increased PCa risk [22]. 
Table 2 Variants from candidate gene association studies associated with PCa among Africans (January 1990-September 2020)

\begin{tabular}{|c|c|c|c|c|c|c|c|c|c|}
\hline Study & Population & $\begin{array}{l}\text { Number of } \\
\text { case/controls }\end{array}$ & $\begin{array}{l}\text { Genotyping } \\
\text { method }\end{array}$ & Gene & SNP & Risk allele & $\begin{array}{l}\text { RAF- } \\
\text { Cases }\end{array}$ & $\begin{array}{l}\text { RAF- } \\
\text { Control }\end{array}$ & OR $(95 \% \mathrm{CI})$ \\
\hline \multirow{8}{*}{$\begin{array}{l}\text { Fernandez et al., } \\
\text { [53] }\end{array}$} & \multirow{8}{*}{$\begin{array}{l}\text { South } \\
\text { African men }\end{array}$} & \multirow{8}{*}{$151 / 134$} & \multirow{8}{*}{$\begin{array}{l}\text { ABI } 3100 \\
\text { Multiplex } \\
\text { SNaPshot }{ }^{\mathrm{me}} \\
\text { Primer } \\
\text { extension } \\
\text { analysis }\end{array}$} & \multirow{8}{*}{ COX-2 } & \multirow[t]{3}{*}{ rs3918304 } & \multirow{3}{*}{ G } & \multirow{3}{*}{0.44} & \multirow{3}{*}{0.21} & AG: $3.39(2.04-5.73)^{* *}$ \\
\hline & & & & & & & & & GG: $5.52(1.59-25.72)^{*}$ \\
\hline & & & & & & & & & Additive: $3.53(2.14-5.90)^{* *}$ \\
\hline & & & & & \multirow[t]{3}{*}{ rs 20415} & \multirow{3}{*}{$\mathrm{T}$} & \multirow{3}{*}{0.44} & \multirow{3}{*}{0.25} & CT: $3.15(1.89-5.34)^{* *}$ \\
\hline & & & & & & & & & CC: $1.88(0.59-6.36)$ \\
\hline & & & & & & & & & Additive: $3.01(1.82-5.02)^{* *}$ \\
\hline & & & & & rs5270 & $\mathrm{G}$ & 0.06 & 0.02 & CG: $2.56(0.98-7.58)$ \\
\hline & & & & & Haplotype & GTC & 0.31 & 0.16 & $3.54(2.12-5.92) * *$ \\
\hline \multirow[t]{3}{*}{ Fawzy et al., [54] } & \multirow[t]{3}{*}{ Egyptians } & \multirow[t]{3}{*}{$112 / 120$} & \multirow[t]{3}{*}{ PCR-RFLP } & \multirow{3}{*}{ COX-2 } & \multirow{3}{*}{ rs2745557 } & \multirow{3}{*}{ G } & \multirow{3}{*}{0.62} & \multirow{3}{*}{0.16} & GA: $13.3(6.7-26.3) * *$ \\
\hline & & & & & & & & & GG: $17.5(6.1-50.4)^{* *}$ \\
\hline & & & & & & & & & G-allele: $5.1(3.3-7.7)^{* *}$ \\
\hline \multirow[t]{2}{*}{ Souiden et al., [55] } & \multirow{2}{*}{\begin{tabular}{|l|} 
Tunisian \\
population
\end{tabular}} & $110 / 122$ & Multiplex & & GSTM1 & GSTM1 0/0 & 0.25 & 0.27 & $0.89(0.53-1.49)$ \\
\hline & & & PCR & GST & GSTT1 & GSTT1 o/0 & 0.62 & 0.48 & $2.17(1.13-4.16)^{*}$ \\
\hline Benabdelkrim $\quad e t$ & Algerian & $49 / 41$ & Multiplex & & GSTM1 & GSTM1 0/0 & 0.22 & 0.08 & $3.69(1.30-10.44)^{*}$ \\
\hline al., [56] & Population & & PCR & GST & GSTT1 & GSTT1 0/0 & 0.10 & 0.10 & $0.92(0.32-2.62)$ \\
\hline Said et al., [57] & Tunisian & $110 / 266$ & Conventional & & & & & & D/I: $1.46(0.87-2.46)$ \\
\hline & population & & PCR & $\mathrm{XPC}$ & XPC-PAT & I & 0.36 & 0.25 & I/I: $(3.831 .83-8.05)^{* *}$ \\
\hline & & & & & & & & & Additive: $(1.871 .16-3.01)^{*}$ \\
\hline Djomkam et al., & Cameroon & $103 / 80$ & PCR-RFLP & & & & & & Ser/Leu: $0.75(\mathrm{n} / \mathrm{a})$ \\
\hline & & & & ELAC2 & Ser217Leu & Leu & 0.47 & 0.38 & Leu/Leu: $6.08(\mathrm{n} / \mathrm{a})^{*}$ \\
\hline Sfar et al., [60] & Tunisian & $101 / 105$ & RFLP-PCR & & & & & & TC: $0.53(0.26-1.06)^{*}$ \\
\hline & population & & & HSP70 & rs2227956 & $\mathrm{C}$ & 0.13 & 0.21 & CC: $0.42(0.1-0.64)$ \\
\hline & & & & & & & & & Additive: $0.51(0.26-0.97)^{*}$ \\
\hline & & & & & & & & & T-allele: $0.54(0.25-1.2)$ \\
\hline Akinloye et al., & \begin{tabular}{|l} 
Nigerians \\
\end{tabular} & $70 / 123$ & fragment & & CAG repeat & GAG repeat & & & $>21: 0.51(0.29-0.93)^{*}$ \\
\hline & & & length & AR & & & & & $\leq 19: 3.66(1.91-7.01)^{* *}$ \\
\hline & & & analysis & & GGN repeat & GGN repeat & & & $>21: 1.62(0.90-2.92)$ \\
\hline & & & & & & & & & $\leq 19: 0.62(0.34-1.11)$ \\
\hline Souiden et al., [47] & Tunisian & $125 / 125$ & RFLP-PCR & CYP17 & rs743572 & C & & & $\mathrm{A} 1 / \mathrm{A} 2: 1.83(1.06-3.16)^{*}$ \\
\hline & population & & & & & & & & $\mathrm{A} 2 / \mathrm{A} 2: 2.02(0.90-4.52)$ \\
\hline & & & & & & & & & Additive: $1.78(1.06-3.01)^{*}$ \\
\hline & & & & & & & & & A2-allele: $1.48(1.03-2.13)^{*}$ \\
\hline Fernandez et al., & South & $281 / 287$ & PCR-RFLP & CYP3A5 & rs776746 & A & 0.29 & 0.21 & $1.37(1.04-1.82)$ \\
\hline [46] & African & & & CYP3A4 & rs2740574 & $\mathrm{G}$ & 0.28 & 0.13 & $2.51(1.76-3.61) * *$ \\
\hline & Population & & & CYP3A43 & rs501275 & $\mathrm{C}$ & 0.21 & 0.14 & $1.60(1.13-2.29)$ * \\
\hline & & & & & & GGT & 0.06 & 0.04 & $2.43(1.26-4.68)$ * \\
\hline & & & & CYP $3 \mathrm{~A}^{*}$ & ${ }^{*} 3 \mathrm{~A} 43$ & AGT & 0.08 & 0.04 & $2.61(1.38-4.94)^{\star *}$ \\
\hline & & & & & & AGC & 0.10 & 0.05 & $2.79(1.59-4.92) * *$ \\
\hline & & & & & & GGC & 0.03 & 0.01 & $4.45(1.32-15.00)^{*}$ \\
\hline
\end{tabular}

Color representation: ash, variants are transferable in some population group but not others

There was no evidence of pedigree or affected-sibling pair studies to understand the genetic contribution of PCa heritability in Africa. The impact of this is that most of the GWAS Consortium are largely focused on potential ancestors of AA, excluding largely the Northern, Middle, and other parts of African countries unexplored [61, 62].

There are significant individual and population-level differences in prostate cancer risk such that the inclusion of a new set of the population will result in a new ancestry-specific signal [44]. Currently, the GWAS approach identified common, low-penetrance, and shared
PCa predisposing variants among the African population. These common SNPs have high penetrance (MAF of at least 5\%) with modest effect sizes and explain about $12 \%$ of the genetic contribution to PCa risk [33], leaving the majority of risk unexplained. The rare variant hypothesis [63] may be substantial in this regard, which necessitates the need to go beyond the commonly used SNP arrays in GWAS. Accordingly, high-coverage targeted or whole-genome sequencing in a larger sample will provide sufficient statistical power to allow a direct variant-by-variant analysis [64]. 
Current efforts in the genetics of PCa have a goal towards personalized therapy for patients. Thus, important genetic epidemiological and functional studies are needed to understand the role of these variants. However, there is no consensus on the genetic architecture of Africans. In terms of individual risk profiling, the functional aspects of these variants are needed for targeted treatment programs. Thus, a wide range of genetic consortia is needed to interrogate the genomes of the African population by pooling efforts and resources.

\section{Conclusion}

The genetic architecture of PCa in Africa provides important contributions to the global understanding of PCa specifically the African-ancestry hypothesis. Although African ancestry has been successfully used to fine-mapped important variants, it only explains $30-33 \%$ of prostate cancer heritability. However, to what extent and aspects to which genetic variants explain PCa heritability in Africa are limited. Therefore, more prostate cancer consortiums are needed to justify the heritable certainties of $\mathrm{PCa}$ among Africans, and emphasis should be placed on the genetic epidemiological model of $\mathrm{PCa}$ in Africa. What we can appreciate is that the use of comprehensive methods in the search for genetic variants and functions have highlighted important candidate genes that perform a special function in PCa biology.

\section{Abbreviations}

AA: African Americans; GWAS: Genome-wide association studies; miRNAs: MicroRNAs; SNPs: Single-nucleotide polymorphisms; SSA: SubSaharan Africa; PCa: Prostate cancer

\section{Acknowledgements}

None

\section{Authors' contributions}

EA and EAA: conception and methodology; EA and EAA: data curation, inclusion, and exclusion criteria. EA and EAA: original draft; EA, EAA, EOA, GA, MAG, ENA, CKSG, FAY, OAA, JY, and CO: writing and editing; supervision: CKSG, FAY, and CO. The authors read and approved the final manuscript.

\section{Funding}

No funding was obtained for this study.

Availability of data and materials

Not applicable

\section{Declarations}

Ethics approval and consent to participate

Not applicable.

\section{Consent for publication}

Not applicable.

\section{Competing interests}

The authors declare that they have no competing interests.

\section{Author details}

${ }^{1}$ Department of Molecular Medicine, College of Health Sciences, School of Medical Science, Kwame Nkrumah University of Science and Technology (KNUST), Kumasi, Ghana. ${ }^{2}$ School of Medical and Health Science, Edith
Cowan University, Joondalup, Australia. ${ }^{3}$ Urology Unit, Department of Surgery, Komfo Anokye Teaching Hospital (KATH), Kumasi, Ghana. ${ }^{4}$ Department of Pathology, Police Hospital, Accra, Ghana. ${ }^{5}$ Department of Pathology, Komfo Anokye Teaching Hospital, Kumasi, Ghana. ${ }^{6}$ Department of Surgery, Komfo Anokye Teaching Hospital, Kumasi, Ghana. ${ }^{7}$ Department of Medical Diagnostics, Faculty of Allied Health Sciences, KNUST, Kumasi, Ghana.

Received: 2 January 2021 Accepted: 16 March 2021

Published online: 30 March 2021

\section{References}

1. Ferlay J, Soerjomataram I, Dikshit R, Eser S, Mathers C, Rebelo M, Parkin DM, Forman D, Bray F (2015) Cancer incidence and mortality worldwide: sources, methods and major patterns in GLOBOCAN 2012. Int J Cancer. 136(5):E359E386. https://doi.org/10.1002/ijc.29210 Epub 2014/09/16. PubMed PMID: 25220842

2. Adeloye $D$, David RA, Aderemi AV, Iseolorunkanmi A, Oyedokun A, Iweala EEJ, Omoregbe N, Ayo CK (2016) An estimate of the incidence of prostate cancer in Africa: a systematic review and meta-analysis. Plos One. 11(4): e0153496. https://doi.org/10.1371/journal.pone.0153496

3. Arbyn M, Castellsagué X, de Sanjosé S, Bruni L, Saraiya M, Bray F, Ferlay J (2011) Worldwide burden of cervical cancer in 2008. Ann Oncol. 22(12): 2675-2686. https://doi.org/10.1093/annonc/mdr015

4. Organization WH. World Health Organization cancer fact sheet. 2009.

5. Farmer P, Frenk J, Knaul FM, Shulman LN, Alleyne G, Armstrong L, Atun R, Blayney D, Chen L, Feachem R, Gospodarowicz M, Gralow J, Gupta S, Langer A, Lob-Levyt J, Neal C, Mbewu A, Mired D, Piot P, Reddy KS, Sachs JD, Sarhan M, Seffrin JR (2010) Expansion of cancer care and control in countries of low and middle income: a call to action. Lancet. 376(9747): 1186-1193. https://doi.org/10.1016/S0140-6736(10)61152-X

6. Taitt HE (2018) Global trends and prostate cancer: a review of incidence, detection, and mortality as influenced by race, ethnicity, and geographic location. Am J Men's Health. 12(6):1807-1823. https://doi.org/10.1177/1 557988318798279

7. Murray CJ, Vos T, Lozano R, Naghavi M, Flaxman AD, Michaud C et al (2012) Disability-adjusted life years (DALYS) for 291 diseases and injuries in 21 regions, 1990-2010: a systematic analysis for the Global Burden of Disease Study 2010. lancet. 380(9859):2197-2223. https://doi.org/10.1016/S0140-673 6(12)61689-4

8. Lozano R, Naghavi M, Foreman K, Lim S, Shibuya K, Aboyans V, Abraham J, Adair T, Aggarwal R, Ahn SY, AlMazroa MA, Alvarado M, Anderson HR, Anderson LM, Andrews KG, Atkinson C, Baddour LM, Barker-Collo S, Bartels $\mathrm{DH}$, Bell ML, Benjamin EJ, Bennett D, Bhalla K, Bikbov B, Abdulhak AB, Birbeck G, Blyth F, Bolliger I, Boufous S, Bucello C, Burch M, Burney P, Carapetis J, Chen H, Chou D, Chugh SS, Coffeng LE, Colan SD, Colquhoun S, Colson KE, Condon J, Connor MD, Cooper LT, Corriere M, Cortinovis M, de Vaccaro KC, Couser W, Cowie BC, Criqui MH, Cross M, Dabhadkar KC, Dahodwala N, de Leo D, Degenhardt L, Delossantos A, Denenberg J, Des Jarlais DC, Dharmaratne SD, Dorsey ER, Driscoll T, Duber H, Ebel B, Erwin PJ, Espindola P, Ezzati M, Feigin V, Flaxman AD, Forouzanfar MH, Fowkes FGR, Franklin R, Fransen M, Freeman MK, Gabriel SE, Gakidou E, Gaspari F, Gillum RF, Gonzalez-Medina D, Halasa YA, Haring D, Harrison JE, Havmoeller R, Hay RJ, Hoen B, Hotez PJ, Hoy D, Jacobsen KH, James SL, Jasrasaria R, Jayaraman S, Johns N, Karthikeyan G, Kassebaum N, Keren A, Khoo JP, Knowlton LM, Kobusingye O, Koranteng A, Krishnamurthi R, Lipnick M, Lipshultz SE, Ohno SL, Mabweijano J, Maclntyre MF, Mallinger L, March L, Marks GB, Marks R, Matsumori A, Matzopoulos R, Mayosi BM, McAnulty JH, McDermott MM, McGrath J, Memish ZA, Mensah GA, Merriman TR, Michaud C, Miller M, Miller TR, Mock C, Mocumbi AO, Mokdad AA, Moran A, Mulholland K, Nair MN, Naldi L, Narayan KMV, Nasseri K, Norman P, O'Donnell M, Omer SB, Ortblad K, Osborne R, Ozgediz D, Pahari B, Pandian JD, Rivero AP, Padilla RP, Perez-Ruiz F, Perico N, Phillips D, Pierce K, Pope CA III, Porrini E, Pourmalek F, Raju M, Ranganathan D, Rehm JT, Rein DB, Remuzzi G, Rivara FP, Roberts T, de León FR, Rosenfeld LC, Rushton L, Sacco RL, Salomon JA, Sampson U, Sanman E, Schwebel DC, Segui-Gomez M, Shepard DS, Singh D, Singleton J, Sliwa K, Smith E, Steer A, Taylor JA, Thomas B, Tleyjeh IM, Towbin JA, Truelsen T, Undurraga EA, Venketasubramanian N, Vijayakumar L, Vos T, Wagner GR, Wang M, Wang W, Watt K, Weinstock MA, Weintraub R, Wilkinson JD, Woolf AD, Wulf S, Yeh PH, Yip P, Zabetian A, Zheng Z, Lopez AD, Murray CJ (2012) Global and regional mortality from 235 causes of death for 20 age groups in 1990 and 2010: a systematic analysis for the 
Global Burden of Disease Study 2010. Lancet. 380(9859):2095-2128. https:// doi.org/10.1016/S0140-6736(12)61728-0

9. Chu LW, Ritchey J, Devesa SS, Quraishi SM, Zhang H, Hsing AW (2011) Prostate cancer incidence rates in Africa. Prostate Cancer 2011:947870. Epub 2011/08/01, PubMed PMID: 22111004. https://doi.org/10.1155/2011/947870

10. Eque M, Gnangnon FHR, Akele-Akpo MT, Maxwell PD (2019) Cancer incidence in Cotonou (Benin), 2014-2016: first results from the Cancer Registry of Cotonou. Cancer Epidemiol. 59:46-50. https://doi.org/10.1016/j.ca nep.2019.01.006 Epub 2019/01/28. PubMed PMID: 30685574

11. Medhin LB, Achila OO, Syum BE, Gebremichael KH, Said SM, Lobeck $H$ et al (2020) Incidence of prostate cancer in Eritrea: data from the National Health Laboratory, Orotta Referral Hospital and Sembel Hospital 2011-2018. Plos One 15(4):e0232091. https://doi.org/10.1371/journal.pone.0232091 Epub 2020/04/24. PubMed PMID: 32324838; PubMed Central PMCID: PMCP MC7179877

12. Carrilho C, Fontes F, Tulsidás S, Lorenzoni C, Ferro J, Brandão M, Ferro A, Lunet N (2019) Cancer incidence in Mozambique in 2015-2016: data from the Maputo Central Hospital Cancer Registry. Eur J Cancer Prev. 28(4):373376. https://doi.org/10.1097/cej.0000000000000457 Epub 2018/06/26. PubMed PMID: 29939861

13. Okongo F, Ogwang DM, Liu B, Maxwell PD (2019) Cancer incidence in Northern Uganda (2013-2016). Int J Cancer. 144(12):2985-2991. https://doi. org/10.1002/ijc.32053 Epub 2018/12/12. PubMed PMID: 30536374

14. Koon Sun Pat M, Manraj M, Fauzee J, Sewsurn S, Parkin DM, Manraj S (2019) Trends in cancer incidence in the Republic of Mauritius, 1991-2015. Cancer Epidemiol 63:101616. https://doi.org/10.1016/j.canep.2019.101616

15. Elidrissi Errahhali M, Elidrissi Errahhali M, Ouarzane M, Boulouiz R, Bellaoui M (2017) Cancer incidence in eastern Morocco: cancer patterns and incidence trends, 2005-2012. BMC Cancer 17(1):587. https://doi.org/10.1186/s12885-01 7-3597-6 PubMed PMID: 28851324

16. Lichtenstein P, Holm NV, Verkasalo PK, lliadou A, Kaprio J, Koskenvuo M, Pukkala E, Skytthe A, Hemminki K (2000) Environmental and heritable factors in the causation of cancer-analyses of cohorts of twins from Sweden, Denmark, and Finland. N Engl J Med 343(2):78-85. https://doi.org/10.1056/ NEJM200007133430201

17. Hjelmborg JB, Scheike T, Holst K, Skytthe A, Penney KL, Graff RE, Pukkala E, Christensen K, Adami HO, Holm NV, Nuttall E, Hansen S, Hartman M, Czene K, Harris JR, Kaprio J, Mucci LA (2014) The heritability of prostate cancer in the Nordic Twin Study of Cancer. Cancer Epidemiol Prev Biomark 23(11): 2303-2310. https://doi.org/10.1158/1055-9965.EPI-13-0568

18. Verhage BA, Aben KK, Witjes JA, Straatman H, Schalken JA, Kiemeney LA (2004) Site-specific familial aggregation of prostate cancer. Int J Cancer. 109(4):611-617. https://doi.org/10.1002/ijc.20015

19. Mucci LA, Hjelmborg JB, Harris JR, Czene K, Havelick DJ, Scheike T, Graff RE, Holst K, Möller S, Unger RH, McIntosh C, Nuttall E, Brandt I, Penney KL, Hartman M, Kraft P, Parmigiani G, Christensen K, Koskenvuo M, Holm NV, Heikkilä K, Pukkala E, Skytthe A, Adami HO, Kaprio J, for the Nordic Twin Study of Cancer (NorTwinCan) Collaboration (2016) Familial risk and heritability of cancer among twins in Nordic countries. JAMA. 315(1):68-76. https://doi.org/10.1001/jama.2015.17703

20. Rebbeck TR (2017) Prostate cancer genetics: variation by race, ethnicity, and geography. Semin Radiat Oncol 27(1):3-10. https://doi.org/10.1016/j.semra donc.2016.08.002

21. Eeles R, Goh C, Castro E, Bancroft E, Guy M, Al Olama AA et al (2014) The genetic epidemiology of prostate cancer and its clinical implications. Nat Rev Urol. 11(1):18-31. https://doi.org/10.1038/nrurol.2013.266

22. Fall B, Ze ondo C, Sarr A, Ouedraogo B, Sow $Y$, Thiam A et al (2015) Détection précoce du cancer de la prostate chez des apparentés de premier degré au Sénégal. Afr J Urol 21(4):225-229. https://doi.org/10.1016/ j.afju.2015.08.002

23. Nemesure B, Wu S-Y, Hennis A, Leske MC (2013) Family history of prostate cancer in a black population. J Immigr Minor Health. 15(6):1107-1112. https://doi.org/10.1007/s10903-012-9710-7 PubMed PMID: 22936456

24. Hayes RB, Liff JM, Pottern LM, Greenberg RS, Schoenberg JB, Schwartz AG, Swanson GM, Silverman DT, Brown LM, Hoover RN, Fralmeni JF Jr (1995) Prostate cancer risk in US blacks and whites with a family history of cancer. Int J Cancer. 60(3):361-364. https://doi.org/10.1002/ ijc.2910600315

25. Whittemore AS, Wu AH, Kolonel LN, John EM, Gallagher RP, Howe GR, West DW, Teh CZ, Stamey T (1995) Family history and prostate cancer risk in black, white, and Asian men in the United States and Canada.
Am J Epidemiol. 141(8):732-740. https://doi.org/10.1093/oxfordjournals.a je.a117495

26. Sanderson M, Coker AL, Logan P, Zheng W, Fadden MK (2004) Lifestyle and prostate cancer among older African-American and Caucasian men in South Carolina. Cancer Causes Control. 15(7):647-655. https://doi.org/10.1 023/B:CACO.0000036172.63845.d4

27. Petersen DC, Jaratlerdsiri W, van Wyk A, Chan EKF, Fernandez P, Lyons RJ et al (2019) African KhoeSan ancestry linked to high-risk prostate cancer. BMC Med Genomics 12(1):82. https://doi.org/10.1186/s12920-019-0537-0 PubMed PMID: 31164124

28. Stefflova K, Dulik MC, Barnholtz-Sloan JS, Pai AA, Walker AH, Rebbeck TR (2011) Dissecting the within-Africa ancestry of populations of African descent in the Americas. Plos one. 6(1):e14495. https://doi.org/10.1371/journal.pone.0014495

29. Murphy AB, Ukoli F, Freeman V, Bennett F, Aiken W, Tulloch T, Coard K, Angwafo F, Kittles RA (2012) 8q24 risk alleles in West African and Caribbean men. Prostate. 72(12):1366-1373. https://doi.org/10.1002/pros.22486

30. Haiman CA, Patterson N, Freedman ML, Myers SR, Pike MC, Waliszewska A, Neubauer J, Tandon A, Schirmer C, McDonald GJ, Greenway SC, Stram DO, le Marchand L, Kolonel LN, Frasco M, Wong D, Pooler LC, Ardlie K, Oakley-Givan I, Whittemore AS, Cooney KA, John EM, Ingles SA, Altshuler D, Henderson BE, Reich D (2007) Multiple regions within 8q24 independently affect risk for prostate cancer. Nat Genet. 39(5):638-644. https:/doi.org/10.1038/ng2015

31. Han Y, Rand KA, Hazelett DJ, Ingles SA, Kittles RA, Strom SS et al (2016) Prostate cancer susceptibility in men of African ancestry at 8q24. J Natl Cancer Inst 108(7). https://doi.org/10.1093/jnci/djv431 Epub 2016/01/30, PubMed PMID: 26823525; PubMed Central PMCID: PMCPMC4948565

32. Chung CC, Hsing AW, Yeboah E, Biritwum R, Tettey Y, Adjei A, Cook MB, de Marzo A, Netto G, Tay E, Boland JF, Yeager M, Chanock SJ (2014) A comprehensive resequence-analysis of $250 \mathrm{~kb}$ region of $8 \mathrm{q} 24.21$ in men of African ancestry. Prostate. 74(6):579-589. https://doi.org/10.1002/pros.22726

33. Du Z, Lubmawa A, Gundell S, Wan P, Nalukenge C, Muwanga P et al (2018) Genetic risk of prostate cancer in Ugandan men. Prostate. 78(5):370-376. https://doi.org/10.1002/pros.23481

34. Fernandez P, Salie M, du Toit $D$, van der Merwe A (2015) Analysis of prostate cancer susceptibility variants in South African men: replicating associations on chromosomes 8q24 and 10q11. Prostate Cancer. 2015: 465184-465186. https://doi.org/10.1155/2015/465184

35. Ahmadiyeh N, Pomerantz MM, Grisanzio C, Herman P, Jia L, Almendro V, He HH, Brown M, Liu XS, Davis M, Caswell JL, Beckwith CA, Hills A, MacConaill L, Coetzee GA, Regan MM, Freedman ML (2010) 8q24 prostate, breast, and colon cancer risk loci show tissue-specific longrange interaction with MYC. Proc Natl Acad Sci. 107(21):9742-9746. https://doi.org/10.1073/pnas.0910668107

36. Pomerantz MM, Beckwith CA, Regan MM, Wyman SK, Petrovics G, Chen Y, Hawksworth DJ, Schumacher FR, Mucci L, Penney KL, Stampfer MJ, Chan JA, Ardlie KG, Fritz BR, Parkin RK, Lin DW, Dyke M, Herman P, Lee S, Oh WK, Kantoff PW, Tewari M, McLeod DG, Srivastava S, Freedman ML (2009) Evaluation of the 8 q24 prostate cancer risk locus and MYC expression. Cancer Res. 69(13):55685574. https:/doi.org/10.1158/0008-5472.CAN-09-0387

37. Cook MB, Wang Z, Yeboah ED, Tettey Y, Biritwum RB, Adjei AA, Tay E, Truelove A, Niwa S, Chung CC, Chokkalingam AP, Chu LW, Yeager M, Hutchinson A, Yu K, Rand KA, Haiman CA, Hoover RN, Hsing AW, Chanock SJ, Consortium AAPCG. A genome-wide association study of prostate cancer in West African men. Hum Genet. 2014;133(5):509-21.

38. Cook MB, Wang Z, Yeboah ED, Tettey Y, Biritwum RB, Adjei AA et al (2014) A genome-wide association study of prostate cancer in West African men. Human Genet. 133(5):509-521. https://doi.org/10.1007/s00439-013-1387-z

39. Conti DV, Wang K, Sheng X, Bensen JT, Hazelett DJ, Cook MB et al (2017) Two novel susceptibility loci for prostate cancer in men of African ancestry. J Natl Cancer Inst 109(8). https://doi.org/10.1093/jnci/djx084 Epub 2017/11/ 09. PubMed PMID: 29117387; PubMed Central PMCID: PMCPMC5448553

40. Akamatsu S, Takata R, Haiman CA, Takahashi A, Inoue T, Kubo M, Furihata M, Kamatani N, Inazawa J, Chen GK, le Marchand L, Kolonel LN, Katoh T, Yamano Y, Yamakado M, Takahashi H, Yamada H, Egawa S, Fujioka T, Henderson BE, Habuchi T, Ogawa O, Nakamura Y, Nakagawa H (2012) Common variants at $11 \mathrm{q} 12,10 \mathrm{q} 26$ and $3 \mathrm{p} 11.2$ are associated with prostate cancer susceptibility in Japanese. Nat Genet. 44(4):426-429. https://doi.org/1 $0.1038 / \mathrm{ng} .1104$

41. Du M, Tillmans L, Gao J, Gao P, Yuan T, Dittmar RL et al (2016) Chromatin interactions and candidate genes at ten prostate cancer risk loci. Sci Rep. $6(1): 1-13$ 
42. Kote-Jarai Z, Al Olama AA, Giles GG, Severi G, Schleutker J, Weischer M et al (2011) Seven prostate cancer susceptibility loci identified by a multi-stage genome-wide association study. Nat Genet. 43(8):785-791. https://doi.org/1 0.1038/ng.882

43. Sun J, Zheng SL, Wiklund F, Isaacs SD, Li G, Wiley KE, Kim ST, Zhu Y, Zhang Z, Hsu FC, Turner AR, Stattin P, Liu W, Kim JW, Duggan D, Carpten J, Isaacs W, Grönberg H, Xu J, Chang BL (2009) Sequence variants at 22q13 are associated with prostate cancer risk. Cancer Res. 69(1):10-15. https://doi. org/10.1158/0008-5472.CAN-08-3464 PubMed PMID: 19117981

44. Harlemon M, Ajayi O, Kachambwa P, Kim MS, Simonti CN, Quiver MH, Petersen DC, Mittal A, Fernandez PW, Hsing AW, Baichoo S. A custom genotyping array reveals population-level heterogeneity for the genetic risks of prostate cancer and other cancers in Africa. Cancer research. 2020; 80(13):2956-66.

45. Haiman CA, Chen GK, Blot WJ, Strom SS, Berndt SI, Kittles RA, Rybicki BA Isaacs WB, Ingles SA, Stanford JL, Diver WR, Witte JS, Hsing AW, Nemesure B, Rebbeck TR, Cooney KA, Xu J, Kibel AS, Hu JJ, John EM, Gueye SM, Watya S, Signorello LB, Hayes RB, Wang Z, Yeboah E, Tettey Y, Cai Q, Kolb S, Ostrander EA, Zeigler-Johnson C, Yamamura Y, Neslund-Dudas C, HaslagMinoff J, Wu W, Thomas V, Allen GO, Murphy A, Chang BL, Zheng SL, Leske MC, Wu SY, Ray AM, Hennis AJM, Thun MJ, Carpten J, Casey G, Carter EN, Duarte ER, Xia LY, Sheng X, Wan P, Pooler LC, Cheng I, Monroe KR, Schumacher F, le Marchand L, Kolonel LN, Chanock SJ, Berg DVD, Stram DO, Henderson BE (2011) Genome-wide association study of prostate cancer in men of African ancestry identifies a susceptibility locus at 17q21. Nat Genet. 43(6):570-573. https://doi.org/10.1038/ng.839 Epub 2011/05/22, PubMed PMID: 21602798

46. Fernandez $P$, De Beer $P$, Van der Merwe L, Heyns C (2010) Genetic variations in androgen metabolism genes and associations with prostate cancer in South African men. South Afr Med J. 100(11):741-745. https://doi.org/10.71 96/SAMJ.4104

47. Souiden Y, Mahdouani M, Chaieb K, Elkamel R, Mahdouani K (2011) CYP17 gene polymorphism and prostate cancer susceptibility in a Tunisian population. Cancer epidemiology. 35(5):480-484. https://doi.org/10.1016/j.ca nep.2010.11.008

48. Souiden Y, Mahdouani M, Chaieb K, Bakhrouf A, Mahdouani K (2012) Lack of association of CYP1A1 polymorphism with prostate cancer susceptibility of Tunisian men. Genet Testing Mol Biomark. 16(7):661-666. https://doi.org/1 $0.1089 / \mathrm{gtmb} .2011 .0212$

49. Fernandez $P$, Zeigler-Johnson CM, Spangler E, van der Merwe A, Jalloh M, Gueye SM, Rebbeck TR (2012) Androgen metabolism gene polymorphisms, associations with prostate cancer risk and pathological characteristics: a comparative analysis between South African and Senegalese men. Prostate Cancer. 2012:1-8. https://doi.org/10.1155/2012/798634

50. Taioli E, Sears V, Watson A, Flores-Obando RE, Jackson MD, Ukoli FA, de Syllos Cólus IM, Fernandez P, McFarlane-Anderson N, Ostrander EA, Rodrigues IS, Stanford JL, Taylor JA, Tulloch-Reid M, Ragin CCR (2013) Polymorphisms in CYP17 and CYP3A4 and prostate cancer in men of African descent. Prostate. 73(6):668-676. https://doi.org/10.1002/pros.22612

51. Apolonia NV, Lorca AR, Alonso MG, Bahri R, Harich N, Cuenca DS, Esteban ME, Santander AF. Genetic diversity of CYP3A4 and CYP3A5 polymorphisms in North African populations: data from Morocco and Tunisia. London: SAGE Publications Sage UK; 2015.

52. Brureau L, Moningo D, Emeville E, Ferdinand S, Punga A, Lufuma S, Blanchet $P$, Romana M, Multigner L (2016) Polymorphisms of estrogen metabolism-related genes and prostate cancer risk in two populations of African ancestry. Plos One. 11(4):e0153609. https://doi.org/10.1371/ journal.pone.0153609

53. Fernandez $P$, de Beer PM, van der Merwe L, Heyns CF (2008) COX-2 promoter polymorphisms and the association with prostate cancer risk in South African men. Carcinogenesis. 29(12):2347-2350. https:/doi.org/10.1093/carcin/bgn245

54. Fawzy MS, Elfayoumi A-R, Mohamed RH, Fatah IRA, Saadawy SF (2016) Cyclooxygenase 2 (rs2745557) polymorphism and the susceptibility to benign prostate hyperplasia and prostate cancer in Egyptians. Biochem Genet. 54(3):326-336. https://doi.org/10.1007/s10528-016-9722-4

55. Souiden Y, Mahdouani M, Chaieb K, Elkamel R, Mahdouani K (2010) Polymorphisms of glutathione-S-transferase $\mathrm{M} 1$ and $\mathrm{T} 1$ and prostate cancer risk in a Tunisian population. Cancer Epidemiol. 34(5):598-603. https://doi. org/10.1016/j.canep.2010.06.002

56. Benabdelkrim M, Djeffal O, Berredjem H (2018) GSTM1 and GSTT1 polymorphisms and susceptibility to prostate cancer: a case-control study of the Algerian population. Asian Pac J Cancer Prev 19(10):2853-2858. https:// doi.org/10.22034/APJCP.2018.19.10.2853

57. Said R, Bougatef K, Boubaker NS, Jenni R, Derouiche A, Chebil M et al (2019) Polymorphisms in XPC gene and risk for prostate cancer. Mol Biol Rep. 46(1):1117-1125. https://doi.org/10.1007/s11033-018-4572-2

58. Djomkam ALZ, Beyeme Sala T, Baari Memba C, Njimoh DL (2019) Prevalence of the Ser217Leu variant of the ELAC2 gene and its association with prostate cancer in population of the Littoral region of Cameroon. Prostate Cancer. 2019:1-6. https://doi.org/10.1155/2019/5974928

59. Akinloye O, Gromoll J, Simoni M (2011) Variation in CAG and GGN repeat lengths and CAG/GGN haplotype in androgen receptor gene polymorphism and prostate carcinoma in Nigerians. Br J Biom Sci. 68(3):138-142. https:// doi.org/10.1080/09674845.2011.11730341

60. Sfar S, Saad H, Mosbah F, Chouchane L (2008) Association of HSP70-hom genetic variant with prostate cancer risk. Mol Biol Rep. 35(3):459-464. https://doi.org/10.1007/s11033-007-9107-1

61. de Vries J, Munung SN, Matimba A, McCurdy S, Oukem-Boyer OOM, Staunton C et al (2017) Regulation of genomic and biobanking research in Africa: a content analysis of ethics guidelines, policies and procedures from 22 African countries. BMC Med Ethics. 18(1):1-9

62. Ayuku S (2017) Establishing a Cancer Research Consortium in low-and middle-income countries: challenges faced and lessons learned

63. Zhang Q (2015) Associating rare genetic variants with human diseases. Front Genet. 6:133

64. Wu X, Gu J (2016) Heritability of prostate cancer: a tale of rare variants and common single nucleotide polymorphisms. Ann Transl Med 4:206. https:// doi.org/10.21037/atm.2016.05.31

\section{Publisher's Note}

Springer Nature remains neutral with regard to jurisdictional claims in published maps and institutional affiliations.

\section{Submit your manuscript to a SpringerOpen ${ }^{\circ}$ journal and benefit from:}

- Convenient online submission

- Rigorous peer review

- Open access: articles freely available online

High visibility within the field

- Retaining the copyright to your article

Submit your next manuscript at $>$ springeropen.com 